\title{
A review study on the traditional plants has potential antidepressant property
}

\begin{abstract}
Depression refers to a state of low mood and aversion to activity characterized by depressed mood, loss of interest, reduced energy and concentration. The reasons for the disease include stimulation of MAO-A, inhibition of NA and 5-HT. Symptoms include the diminished interest of pleasure, feelings of worthlessness or inappropriate guilt, a decrease in appetite and libido, insomnia, and recurrent thoughts of death or suicide. There are plenty of synthetic drugs used to treat depression but not enough blissful for patients, moreover, these synthetic drugs have potential side effects. After decades of serious obsession with the modern medicinal system, people have started looking at the ancient healing systems like Ayurveda, Siddha, and Unani. Many scientists are researching plant material for treating this disorder and there are lots of publications on it. But this is not sufficient for treating depression; further outcome should come into light that's the purpose of our review.
\end{abstract}

Keywords: depression, antidepressant, medicinal plant, force swimming test, tail suspension test, open field test
Volume 4 Issue 5 - 2017

\author{
Md Rashidur Rahman, Mohammad Ali, \\ Mostakim Sharif, Afsana Tajmim \\ Department of Pharmacy, Jessore University of Science \& \\ Technology, Bangladesh
}

Correspondence: Md Rashidur Rahman, Department of Pharmacy, Jessore University of Science \& Technology, Bangladesh, Tel +88017275 10926, Email mr.rahman@just.edu.bd

Received: November 05, 2017 | Published: November 22, 2017
Abbreviations: HBT, hole board test; FST, force swimming test; TST, tail suspension test; OFT, open field test; EPMT, elevated plus maze test; MACT, muscle coordination activity test; THB, triple horizontal bars

\section{Introduction}

Mental depression that distresses a person's mood, thoughts, physical health and behavior is a chronic illness. Biological and emotional components are associated with symptoms of depression. Retardation of thought, action and appetite are biological symptoms \& emotional indicators include mystery, apathy and pessimism, low self- esteem consisting of feeling of guilt, inadequacy and ugliness, indecisiveness and loss of motivation. ${ }^{1}$ World health report shows evidence that about 450 million people all over the world suffer from mental or behavioral syndrome. ${ }^{2,3}$ This extents to $12.3 \%$ of the worldwide affliction of disease, and grounded to rise up to $15 \%$ by $2020 .{ }^{4}$ Patients with major depression have symptoms that reflect changes in brain, monoamine neurotransmitters, specifically nor epinephrine, serotonin, dopamine. ${ }^{5}$ It is estimated that by the year 2020 , depression will result in second greatest increase in morbidity after cardiovascular disease, presenting a significant socioeconomic burden. ${ }^{6}$ Mental depressions are mainly two types, specifically unipolar depression and bipolar depression. In unipolar depression, mood swings are constantly in the identical track and is conjoint (about $75 \%$ of cases) non familial, evidently accompanying with traumatic life events and complemented by indicators of anxiety and agitation. The following type is bipolar depression (about 25\% of cases) occasionally also called as endogenous depression, displays a familiarized pattern, dissimilar to exterior stresses and frequently seems in premature grown-up life, results in vacillating depression and mania over a period of a few weeks. ${ }^{7}$ Although a number of synthetic drugs are being used as the standard treatment for clinically depressed patients, they have adverse effects that can compromise the therapeutic treatment, these common adverse effect include dry mouth, fatigue, gastrointestinal or respiratory problems, anxiety, agitation, drowsiness, and cardiac arrhythmias. Several drug-drug interactions can also occur. These conditions create an opportunity of alternative treatment for depression by the use of medicinal plants. Since all the synthetic drugs available for the treatment of depression have various adverse effects associated with problematic interactions, our aim is to explore the potential of medicinal plants in the management of depression.

\section{Discussion}

This review includes detailed description of antidepressant activity of 21 medicinal plants whose roots, leaves, fruits extracts were used to evaluate the activity from various research articles. The tests employed for antidepressant activity includes HBT, FST, TST, OFT, EPMT, and MACT using rotarod and THB. These tests are employed with slight modification from original method, keeping basic concept same.

\section{HBT}

Exploratory behaviour of rodents such as mice is evaluated using hole board test. The floor of the apparatus has regularly arranged holes. The animal is placed in the arena. Both frequency and duration of spontaneous elicited hole-poking behavior are then measured during a short period of time. This test also provides a simple method for assessing anxious response of a rodent to an unfamiliar environment. The use of the hole-board in this perspective relies on the hypothesis that the behavior of animals exposed to a novel situation results from competition between an exploratory tendency and a withdrawal tendency. Thus, anxiety is inversely related to head-dipping behaviour of mice. Other associated behaviors that can be can be evaluated using the hole board test are grooming, rearing and locomotion. ${ }^{8}$

\section{FST}

FST is also known as behavioral despair test, is a widely used behavioral test for determining antidepressant activity of a compound. This method is described according to Porsolt. ${ }^{9,10}$ In this test, 
experimental animals are divided randomly into control, standard and extract with five animals in each group. Test preparations are administered once daily over a period of 14days. Experiment is separated into two sessions with 24 hours interval. In the first session, animals are placed into an acrylic cylinder individually filled with water for 15 minutes. Immobility is not scored in this session. The objective of this session is to adapt the animals to experimental situation as well as to persuade stable and high level of immobility during test session. Twenty-four hours after the pre-test session, the animals were once again exposed to the same conditions for $5 \mathrm{~min}$ (test session). Between the pretest session and main session, drug solutions are then administered orally three times as follows: just after the pre-test session, $5 \mathrm{~h}$ before the main test, and $1 \mathrm{~h}$ before the main test. A mouse is judged immobile if it remained floating in the water, except for small movements to keep its head above the water.

\section{TST}

Basic concept of the protocol of TST is similar to FST and differs in that immobility is persuaded by suspending the tail of the experimental animal. Before administrating the drug weigh each animal. After administration of the drug, wait for some time to initiate the test, usually $30 \mathrm{~min}$ for intraperitoneal and subcutaneous injections, and $60 \mathrm{~min}$ for oral administration. Animal's tail is wrapped by adhesive tape to a constant position three quarters of the distance from the base tail. The animal was observed continuously for 6 minutes. To prevent bias in animal behavior test should be performed using blind with coded solutions. ${ }^{11}$

\section{OFT}

OFT is used to measure anxiety and exploration as well as locomotion in a large field. Mice were placed into the center or one of the four corners of the open field and allowed to explore the apparatus for 5 minutes. To assess the process of habituation to the novelty of the arena, mice were exposed to the apparatus for 5 minutes on 2 consecutive days. The number of line crosses and the frequency of rearing are usually used as measures of loco motor activity, but are also measures of exploration and anxiety. The number of central square entries and the duration of time spent in the central square are measures of exploratory behaviour and anxiety. A high frequency/ duration of these behaviors' indicates high exploratory behaviour and low anxiety levels. ${ }^{12}$

\section{EPMT}

The elevated plus maze test is one of the most widely used tests for measuring anxiety-like behavior. The test is based on the natural aversion of mice for open and elevated areas, as well as on their natural spontaneous exploratory behavior in novel environments. The apparatus consists of open arms and closed arms, crossed in the middle perpendicularly to each other, and a center area. Mice are given access to all of the arms and are allowed to move freely between them. The number of entries into the open arms and the time spent in the open arms are used as indices of open space-induced anxiety in mice. ${ }^{14}$

\section{MCAT}

Behavior is made manifest by action, and action requires motor skills, including coordination of the body. MCAT is employed to detect antidepressant activity by evaluating muscle activity. Several apparatus along with distinct procedure are described by Deacon et al. ${ }^{13}$
Rotarod: The Rotarod uses a rod with rotating ability, $3 \mathrm{~cm}$ in diameter and supported $30 \mathrm{~cm}$ above the base of the apparatus. The surface is knurled in a series of parallel ridges along the longitudinal axis, enabling the mice to grip it effectively. The start speed is adjusted to $4 \mathrm{rpm}$; the acceleration rate to $20 \mathrm{rpm} / \mathrm{min}$. Maximum speed is $40 \mathrm{rpm}$. Two flanges prevent the mouse from leaving the rod. They are $30 \mathrm{~cm}$ in diameter (this could probably be reduced to $20 \mathrm{~cm}$ ). Their separation is set at $6 \mathrm{~cm}$ (maximum) but may need to be adjusted smaller for subadult mice if they tend to turn around on the rod.

THB: The bars are made of brass, $38 \mathrm{~cm}$ long, held $49 \mathrm{~cm}$ above the bench surface by a wooden support column at each end. The columns are secured to a heavy wooden base. Three bar diameters are available: 2, 4 and $6 \mathrm{~mm}$. The $2 \mathrm{~mm}$ bar is the standard, but many mice reach maximum scores on this. Therefore larger diameter bars have been included in an attempt to refine the test, as mice cannot grip these so well.

\section{Traditional plants having potential antidepressant activity \\ Centella asiatica Linn}

Centella asiatica (CA), a clonal, perennial herbaceous creeper belongs to the family umbellifere (Apiceae). Preliminary phytochemical studies showed the presence of Saponins, Terpenoids, Alkaloids, and Phenols. ${ }^{15}$ The plant possess cardiotonic, nerve tonic, sedative to nerves, stomachic, carminative, improves appetite, antileprotic, memory and febrifuge. ${ }^{16}$ Several investigations have proposed that this plant possess sedative and anxiolytic, ${ }^{17}$ antiepileptic, ${ }^{18}$ memory enhancing, ${ }^{19}$ cardioprotective ${ }^{20}$ and immunomodulation activity. This plant also found to possess antidepressant activity. ${ }^{21}$

\section{Momordica charantia}

This plant is known as bitter melon, bitter gourd, balsam pear, karela, and pare. It grows in tropical areas of the Amazon, East Africa, Asia, India, South Africa, and the Caribbean and is used traditionally as both food and medicine. Its phytochemicals are alkaloids, flavonoids, glycosides, triterpenoids, steroids, phenols, tannins, oils and fats. ${ }^{22,23} \mathrm{M}$. charantia has also been already documented as antidepressant and antianxiety herb. Yet, very less data available on systematic biological investigation about leaves, seeds and root $^{24,25}$ of this plant and fruit has never been subjected to systematic biological investigation. The antidepressant activity of unripe fruit along with leaves of M. charantia is evaluated using stress induced depression models like FST and TST. ${ }^{26,27}$

\section{Tecoma stans}

Flowers of Tecoma Stan Linn popularly known as "yellow bell flowers" contain flavonoids. Leaves of Tecoma Stan contain the alkaloids tecomin and tecostamine are potent hypoglycemic agent when given intravenously. Anthranilic acid is responsible for the ant diabetic activity. Roots are powerful diuretic and vermifuge. ${ }^{28}$ Tecoma is not a toxic because this plant is used in Latin America as a remedy for diabetes and moreover for feeding cattle and goats in Mexico. ${ }^{29}$ Flavonoids have been established to have antidepressant activity. ${ }^{30}$

\section{Clitoria ternatea}

Clitoria ternatea (CT), a perennial herbaceous plant commonly known as 'butterfly pea', has been used for centuries as a traditional 
Ayurvedic medicine. The roots have laxative, diuretic, anthelmintic and anti-inflammatory properties, and they are useful in severe bronchitis, asthma and hectic fever. ${ }^{31,32}$ Clitoria ternatea has been reported for nootropic, anxiolytic, anticonvulsant, ${ }^{33}$ anti-diabetic, ${ }^{34}$ and antipyretic, anti-inflammatory and analgesic activities, ${ }^{35}$ among others. It enhances the memory ${ }^{36}$ and increases acetylcholine content in rats ${ }^{37}$ as well as antidepressant activity. ${ }^{38}$

\section{Cucurbita pepo}

The species, Cucurbito pepo is a cultivated plant of the genus Cucurbita. Aqueous and alcoholic extract of Cucurbita pepo produced significant antidepressant-like effect in mice in FST and its efficacy was found to be similar to Imipramine. This test is quite sensitive and relatively specific to all major classes of antidepressant drugs. In FST, rats are forced to swim in restricted space from which they cannot escape. This induces a state of behavioral despair in animals, which is claimed to reproduce a condition similar to human depression. ${ }^{39}$

\section{Aegle marmelos}

Aegle marmelos (AM), a highly reputed Ayurvedic medicinal tree commonly known as the bael fruit tree is found all over India. The tree is endowed with various medicinal properties. Several studies on different parts of AM showed that the plant possess Antidiarrhoeal, ${ }^{40}$ antidiabetic, ${ }^{41}$ anticancer ${ }^{42}$ radio protective, ${ }^{43}$ antifungal, ${ }^{44}$ antimicrobial, ${ }^{45}$ anti micro filarial, ${ }^{46}$ anti-inflammatory, antipyretic and analgesic activities. ${ }^{47}$ Methanol leaf extract of Aegle marmelos showed significant anxiolytic and antidepressant activities possibly by increasing monoamines level at post synaptic sites. Hence Aegle marmelos may be served as a potential resource for natural psychotherapeutic agent against stress related disorders such as anxiety and depression. ${ }^{48}$

\section{Rosmarinus officinalis}

Rosmarinus officinalis, traditionally known as rosemary, grows wild in most Mediterranean countries. ${ }^{49}$ It is often cultivated for its great quantity of essential oils used in the perfume industry and as a flavoring agent. Rosemary has been widely used in traditional medicines and it has been found to have significant antioxidant activity. ${ }^{50}$ It has long been known as the herb of remembrance, ${ }^{51}$ and it has been reported that memory is improved with the use of R. Officinalis. ${ }^{52,53}$ Salvigenin, rosmanol and cirsimaritin compound was isolated from Rosmarinus officinalis. It was also found to have antidepressant activity. ${ }^{54}$

\section{Melissa officinalis}

Melissa officinalis (Lamiaceae) or lemon balm is an herbal medicine native to the eastern Mediterranean region and western Asia. Dried or fresh leaves and top aerial section of the plant are the parts which are used as medicine.$^{55}$ Lemon balm has been traditionally used for different medical purposes as tonic, antispasmodic, carminative, diaphoretic, surgical dressing for wounds, sedative-hypnotic, strengthening the memory, and relief of stress induced headache. ${ }^{56}$ It is currently used for the relief of stress-induced headache, as a mild sedative-hypnotic, and as an antiviral to improve healing of herpes simplex cold sores. ${ }^{57}$ All doses of the aqueous extract, used in the study, produced a significant reduction in immobility along with an increase in climbing behavior which is similar to those which have been observed with Imipramine. Essential oil caused a dose-dependent reduction in immobility and an increase in climbing at all studied doses, compared to control group. Only the highest dose (300mg/kg) of essential oil showed a significant increase in swimming behavior.
The aqueous extract, but not the essential oil, decreased spontaneous activity in a dose dependent manner. ${ }^{58}$

\section{Cassia occidentalism}

Cassia Occidentalism is a native plant of southern India, called as Kasmard in Sanskrit, Kasondi in Hindi and Coffee senna in English belongs to family Caesalpiniaceous. Its common name is ponnavari. The parts used are leaves, seeds and roots. It is used for fever, menstrual problems, tuberculosis and as a tonic for general weakness and illness. ${ }^{59}$ Cassia occidentalis leaf extracts have antibacterial, ${ }^{60-62}$ antiplasmodial, ${ }^{63}$ antimutagenic, ${ }^{64}$ hepatoprotective ${ }^{65}$ and anti-diabetic activity ${ }^{66}$ The plant was also evaluated for the antianxiety and antidepressant activity. ${ }^{67}$

\section{Basella alba L}

Basella alba L. (Synonym: Basellarubra Roxb.) is an extremely heat tolerant, ${ }^{68}$ fast growing perennial vine which belongs to family Basellaceae. ${ }^{69}$ It is commonly known as Malabar spinach, Indian spinach, Ceylon spinach, vine spinach, ${ }^{70}$ climbing spinach, ${ }^{71}$ EastIndian spinach, Chinese spinach ${ }^{72}$ and cyclone spinach. ${ }^{73}$ Basella is native to tropical Southern Asia, probably originated from India or Indonesia. ${ }^{74}$ Numerous bioactive compounds such as flavonoids, Saponins, Phenolic and tannins have been isolated from leaves of Basella alba. They are found to possess antidepressant activity. ${ }^{75}$

\section{Passiflora foetida}

Passiflora foetida (Passifloraceae), popularly known as stinking passion flower, is an herbaceous climber that has been widely used in Mexican traditional medicine for the treatment of different central nervous system (CNS) disorders. Chemical constituents in Passiflora foetida include hydrocyanic acid, groups of flavonoids and Harman alkaloids. ${ }^{76}$ Some reports have pointed out the harman alkaloids as the bioactive constituents of Passiflora incarnata Linn, one of the species of Passiflora that have been extensively studied chemically and biologically. ${ }^{77,78}$ It has found to possess antidepressant activity. ${ }^{79}$

\section{Urtica dioica}

The present study indicates that Urtica dioica produces a specific antidepressant-like effect in animal models predictive of antidepressant properties, FST and TST. Moreover, the effect of the acute or repeated administration of this extract was similar to the action produced by the classical antidepressant fluoxetine and haloperidol. ${ }^{80}$

\section{Andrographis paniculata}

Andrographis paniculata (Acanthaceae) is an Indian herbal medicine used as an anti-inflammatory and antipyretic drug for the treatment of fever, cold, laryngitis, diarrhea, and rheumatoid arthritis. ${ }^{81}$ The behavioral despair model was performed in order to investigate the ability of this herbal drug in the elevation of suppressed mood, which is quite common in today's scenario. The results obtained from FST and TST clearly reveals the fact that this drug is potentially quite useful in cases of depression. ${ }^{82}$

\section{Hypericum species ( $H$. perforatum $L$. and $H$. maculatum C)}

Hypericum perforatum L. (Hypericaceae), commonly known as St. John's wort, is one of the best investigated medicinal plants. Hypericum perforatum L. (Hypericaceae). H. perforatum is widely used for the treatment of mild to moderate forms of depression. Some well documented clinical studies ${ }^{83}$ had shown that alcoholic extract 
from these plants have at least the same efficiency as the conventional drugs but with far less side effects. It has been suggested that $\mathrm{H}$. maculatumhas antipanic and anxiolytic effects on human subjects. ${ }^{84}$

\section{Eicchornea crassipes}

Eicchornea crassipes commonly known as water hyacinth is a free-floating perennial aquatic plant belongs to the family of Pontederiaceae. The primary chemical constituents are carbohydrates, alkaloids, flavonoids, tannins, saponins, terpenoids, alkaloids, proteins, and phenols they also contain iron, manganese, and zinc..$^{85}$ In the traditional medicine, E. crassipes used as nervine tonic, stimulant, antispasmodic, antioxidant, antidepressant. ${ }^{86}$

\section{Selaginella bryopteris}

Selaginella bryopteris is a pteridophytic plant belongs to the family selaginellaceae. Its familiar name is sanjeevani booti. Selaginella bryopteris is a lithophytes that grows on the hills of tropical areas, particularly the arawali mountain terrain from east to west in India and the plants grow luxuriantly during rains exhibiting a lush green velvety landscape. During summer the plants undergo extreme desiccation; fronds curl and become dry virtually dead. In this condition they look like closed fist hence often known in Unani as punjemeriam or hathazori. The dry plants when left in water unfold their fronds, turn green and come back to active life. This plant has been found to have antidepressant activity. ${ }^{87}$

\section{Artemisia absinthium}

Artemisia absinthium (Asteraceae) is widely used in Iranian traditional medicine. Artemisia absinthium L. (wormwood) (Asteraceae) is an aromatic-bitter herb, used as traditionally in Iran. This species known to possess ethno medical and biological properties related to anthelmintic activity, ${ }^{88}$ antifungal, ${ }^{89}$ antimicrobial activity ${ }^{90}$ choleretic, antiseptic, balsamic, depurative, digestive, diuretic, emmenagogue and in treating leukemia and sclerosis. ${ }^{9}$ Essential oil composition of this species was reported previously. ${ }^{92}$ Its antidepressant activity was also established..$^{93}$

\section{Alafia multifora}

Alafia multifora (Apocynaceae) is a medicinal plant widely distributed in the tropical region of Africa Phytochemical screening of the stem bark showed the presence of phenols, tannins, flavonoids, anthraquinones, and alkaloids. ${ }^{94} \mathrm{~A}$ wide range of plant-derived flavonoids, terpenes, can cross the blood-brain barrier and are able to influence brain function ${ }^{95}$ such as the modulation of the function of inotropic GABA receptors. Due to the presence of flavonoids in the extract of A. Multifora and its higher antioxidant activities, it is presumed that this plant might have pharmacological effects at the level of the central nervous system including antidepressant activity. ${ }^{96}$

\section{Citrus maxima}

Citrus maxima Merr. (Rutaceae) is known as pummel. It has been used in indigenous system of medicine as sedative in nervous affections, convulsive cough and in the treatment of hemorrhagic diseases and epilepsy ${ }^{97}$ as well as depression. ${ }^{98}$

\section{Rosa damascene}

$\mathrm{R}$. damascene is a medicinal plant that is mostly known in the world for its perfume effect. However, in traditional medicine, it has been used for treatment of abdominal and chest pain, strengthening the heart, menstrual bleeding, and digestive problems. It also has beneficial effects on depression. ${ }^{99}$

\section{Bacopa monniera}

Bacopa monniera (Family: Scrophulariaceae), commonly known as Brahmi, is an aquatic herbs distributed throughout the warmer regions of the world including Bangladesh. In Bangladesh, this plant is extensively used in the traditional medicine system as potent therapeutic agent as a neurological tonic to enhance intellectual development, ${ }^{100}$ to treat epilepsy, ${ }^{101}$ cardiac, ${ }^{102}$ respiratory ${ }^{103}$ and digestive ${ }^{104}$ disorders, toothache and purifies blood. In some parts of this country, Brahmi is used to treat rheumatism and to prevent miscarriage. ${ }^{105}$ Its antidepressant activity was also found (Table 1). ${ }^{106}$

Table I Traditional plants having potential antidepressant property

\begin{tabular}{|c|c|c|c|c|c|c|}
\hline Plant name & Extract & Animal model & $\begin{array}{l}\text { Method of } \\
\text { testing }\end{array}$ & $\begin{array}{l}\text { Reference } \\
\text { standard drug }\end{array}$ & Dose & Reference \\
\hline $\begin{array}{l}\text { Centella asiatica. } \\
\text { Linn }\end{array}$ & $\begin{array}{l}\text { Ethanolic Extract of } \\
\text { Leaves }\end{array}$ & Male Wister rats & $\begin{array}{l}\text { FST } \\
\text { HBT }\end{array}$ & $\begin{array}{l}\text { Imipramine }(30 \mathrm{mg} / \\
\mathrm{kg})\end{array}$ & $\begin{array}{l}100 \mathrm{mg} / \mathrm{kg} \\
300 \mathrm{mg} / \mathrm{kg}\end{array}$ & 21 \\
\hline $\begin{array}{l}\text { Momordica } \\
\text { charantia }\end{array}$ & $\begin{array}{l}\text { Ethanolic Extract of } \\
\text { unripe fruit }\end{array}$ & $\begin{array}{l}\text { Swiss albino female } \\
\text { mice }\end{array}$ & $\begin{array}{l}\text { FST } \\
\text { TST }\end{array}$ & $\begin{array}{l}\text { Imipramine (15 mg/ } \\
\mathrm{kg})\end{array}$ & $\begin{array}{l}100 \mathrm{mg} / \mathrm{kg} \\
300 \mathrm{mg} / \mathrm{kg} \\
500 \mathrm{mg} / \mathrm{kg}\end{array}$ & 27 \\
\hline Tecoma stans & $\begin{array}{l}\text { Methanolic and } \\
\text { aqueous extract of } \\
\text { flowers }\end{array}$ & male Swiss Albino mice & $\begin{array}{l}\text { FST } \\
\text { TST }\end{array}$ & $\begin{array}{l}\text { Imipramine (10 mg/ } \\
\text { kg, i.p.) }\end{array}$ & $\begin{array}{l}30 \mathrm{mg} / \mathrm{kg} \\
100 \mathrm{mg} / \mathrm{kg}\end{array}$ & 30 \\
\hline Clitoria Ternatea & $\begin{array}{l}\text { Ethanolic extract of } \\
\text { root }\end{array}$ & $\begin{array}{l}\text { Swiss albino mice and } \\
\text { albino rats of either sex }\end{array}$ & $\begin{array}{l}\text { OFT } \\
\text { MCAT }\end{array}$ & $\begin{array}{l}\text { Imipramine (15 mg/ } \\
\text { kg, p.o.) }\end{array}$ & $\begin{array}{l}150 \mathrm{mg} / \mathrm{kg} \\
300 \mathrm{mg} / \mathrm{kg}\end{array}$ & 38 \\
\hline Cucurbita pepo & $\begin{array}{l}\text { Alcoholic and } \\
\text { aqueous extract of } \\
\text { seeds }\end{array}$ & Male albino Wistar rats & FST & $\begin{array}{l}\text { Imipramine }(30 \mathrm{mg} / \\
\mathrm{kg})\end{array}$ & 100 mg/ kg & 39 \\
\hline Aegle marmelos & $\begin{array}{l}\text { Methanolic Extract of } \\
\text { Leaves }\end{array}$ & Male Swiss Albino mice & $\begin{array}{l}\text { EPM } \\
\text { TST } \\
\text { Digital } \\
\text { photoactometer }\end{array}$ & $\begin{array}{l}\text { Imipramine }(20 \mathrm{mg} / \\
\mathrm{kg}) \text { and Fluoxetine } \\
(20 \mathrm{mg} / \mathrm{Kg}) \text {. }\end{array}$ & $\begin{array}{l}75 \mathrm{mg} / \mathrm{kg} \\
150 \mathrm{mg} / \mathrm{kg} \\
300 \mathrm{mg} / \mathrm{kg}\end{array}$ & 48 \\
\hline $\begin{array}{l}\text { Rosmarinus } \\
\text { officinalis }\end{array}$ & $\begin{array}{l}\text { Isolation of salvigenin, } \\
\text { rosmanol and } \\
\text { cirsimaritin }\end{array}$ & Male Swiss Albino mice & $\begin{array}{l}\text { FST } \\
\text { TST }\end{array}$ & $\begin{array}{l}\text { Imipramine } \\
(60 \mathrm{mg} / \mathrm{kg})\end{array}$ & $\begin{array}{l}50-200 \mathrm{mg} / \\
\mathrm{kg}\end{array}$ & 54 \\
\hline
\end{tabular}


Table Continued....

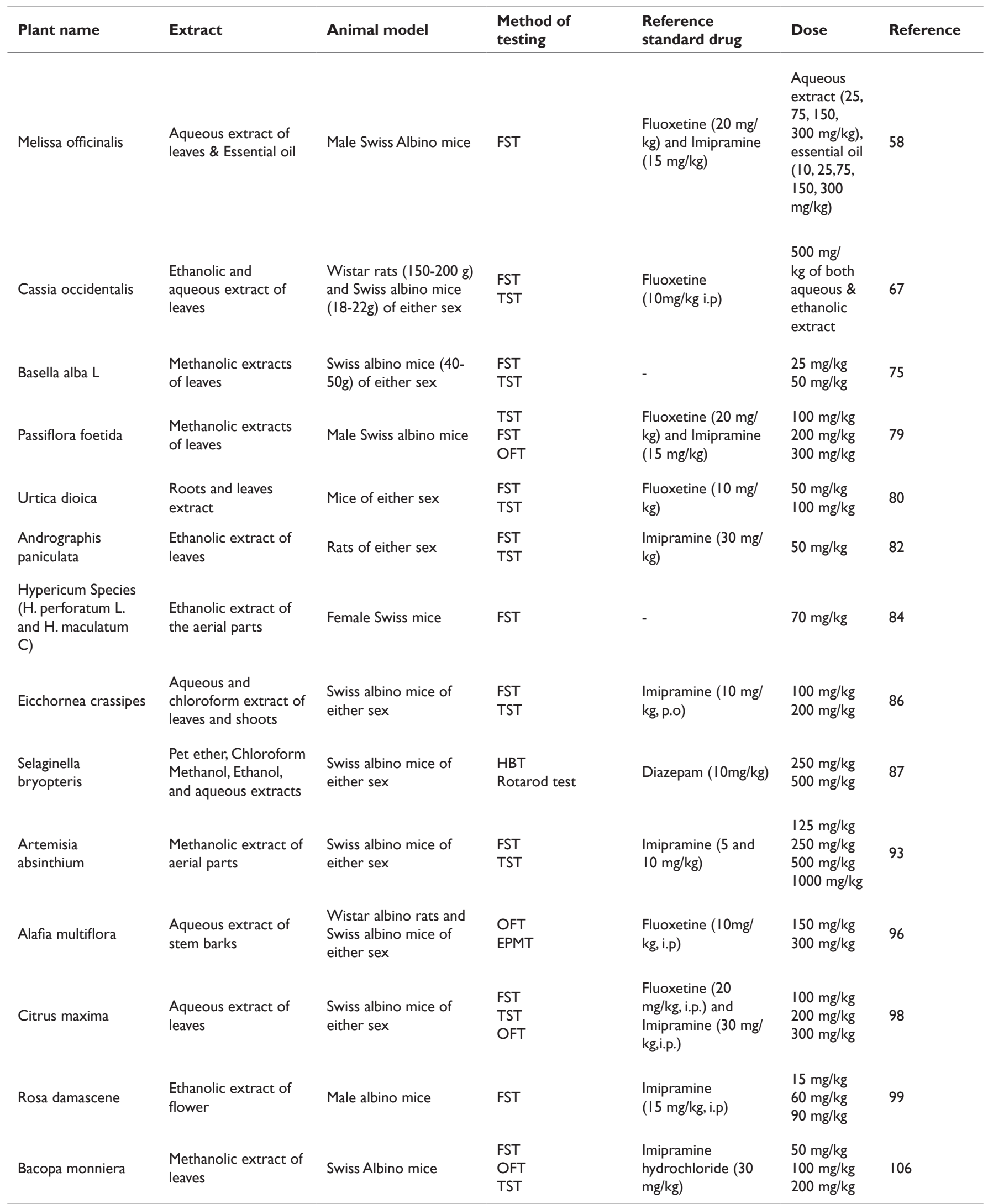

HBT, hole board test; FST, force swimming test; TST, tail suspension test; OFT, open field test; EPMT, elevated plus maze test; MACT, muscle coordination activity test; THB, triple horizontal bars 


\section{Results and discussion}

Since ancient times, people have been using plants in various ways as a source of medicine. We believe that plants having the potential anti-depressant activity can be used as an adjuvant in the treatment of depression and other mood disorders. The collections of herbal plants showing the antidepressant activity were tabulated from the various journals and were reported above. We can conclude that herbal plants are very rich source which is responsible for increasing the antidepressant activity. The plants discussed above having antidepressant property were assessed by different tests. However, further studies are necessary to find the exact mechanism of antidepressant effect and to isolate the active compound (s) responsible for this pharmacological activity.

\section{Conclusion}

Marketed antidepressant drugs used for the depression treatment may cause side effects such as vomiting, nausea, irritation, insomnia, tremor, blurred vision, urinary retention etc. To overcome this, natural medicines are used for treatment of depression which will have very less side effects. The aim of our study is to find out new and innovative treatment of depression having fewer side effect (e,g. sedation and anti cholinergic effect), lower toxicity in higher dose, rapid onset of action, greater efficacy, effective in patients non responsive to TCAs and MAOIs.

\section{Acknowledgements}

None.

\section{Conflict of interest}

The author declares no conflict of interest.

\section{References}

1. Rang HP, Dale MM, Ritter JM. Pharmacology. 4th ed. Scotland: Churchill Livingstone; 2000. 550 p.

2. Gautam RK, Dixit PK, Mittal S. Herbal Sources of Antidepressant Potential: A Review. Int J Pharm Sci Rev Res. 2013;18(1):86-91.

3. WHO. The World Health Report-Mental health: new understanding new hope. Geneva: WHO; 2001.

4. Reynolds EH. Brain and Mind: A Challenge for WHO. Lancet. 2003;361(9373):1924-1925.

5. Gold PW, Goodwin FK, Chrousos GP. Clinical and Biochemical Manifestations of Depression. N Engl J Med. 1988;319(6):348-353.

6. WHO. Mental and Neurological Disorders 'Depression'. World Health Organization; 2001. p. 1-4.

7. Rang HP, Dale MM, Ritter JM. Pharmacology. 5th ed. Scotland: Churchill Livingstone; 2003. p. 1-535.

8. Holeboard test. Panlab.

9. Porsolt RD, Le Pichon M, Jalfre M. Depression: a new animal model sensitive to antidepressant treatments. Nature. 1977;266(5604):730-732.

10. Porsolt RD, Bertin A, Jalfre M. Behavioural despair in mice: a primary screening test for antidepressants. Arch Int Pharmacodyn Ther. 1977;229(2):327-336.

11. Steru L, Chermat R, Thierry B, et al. The tail suspension test: a new method for screening antidepressants in mice. Psychopharmacology. 1985;85(3):367-370.
12. Carlini EA, Contar JDD, Silva-Filho AR, et al. Pharmacology of lemongrass (Cymbopogon citratus Stapf). I. effects of teas prepared from the leaves on laboratory animals. $J$ Ethnopharmacol. 1986;17(1):37-64.

13. Deacon RM. Measuring motor coordination in mice. J Vis Exp. 2013;75:e2609.

14. Komada M, Takao K, Miyakawa T. Elevated plus maze for mice. J Vis Exp. 2008;22:1-4.

15. Singh B, Rastogi RP. A reinvestigation of the triterpenes of Centella asiatica. Phytochemistry. 1969;8(5):917-921.

16. Agarwal VS. Economic plants of India. India: FAO; 1990. 127 p.

17. Ramanathan M, Sivakumar S, Anandvijayakumar PR, et al. Neuroprotective evaluation of standardized extract of Centella asiatica in monosodium glutamate treated rats. Ind J of Exp Bio. 2007;45(5):425431.

18. Gupta YK, Veerendrakumar MV, Srivatsava AK. Effect of Centella asiatica on pentylenetetrazole-induced kindling, cognition and oxidative stress in rats. Pharmacol Biochem Behav. 2003;74(3):579-585.

19. Kumar MV, Gupta YK. Effect of different extract of Centella asiatica on cognition and markers of oxidative stress in rats. $J$ Ethnopharmacol. 2002;79(2):253-260.

20. Pragada RR, Veeravalli KK, Chowdary KPR, et al. Cardioprotective activity of Hydrocotyle asiatica $L_{\text {., }}$ in ischemia-reperfusion induced myocardial infarction in rats. J Ethnopharmacol. 2004;93(1):105-108.

21. Selvi PT, Kumar MS, Rajesh R, et al. Antidepressant activity of ethanolic extract of leaves of Centellaasiatica. Linn by In vivo methods. Asian J Res Pharm Sci. 2012;2(2):76-79.

22. Patil SA, Patil SB. Toxicological Studies of Momordica charantia Linn Seed extracts in male mice. Int J Morphol. 2011;29(4):1212-1218.

23. Kokate CK, Purohit AP, Gokhlale SB. Pharmacognosy. 34th ed. India: Nirali Prakashan; 2006. p. 218-219.

24. Gautam RK, Dixit PK, Mittal S. Herbal Sources of Antidepressant Potential: A Review. Int J Pharm Sci Rev Res. 2013;18(1):86-91.

25. Rajput MS, Sinha S, Mathur V, et al. Herbal Antidepressants. Int $J$ Pharma Frontier Res. 2011;1(1):159-169.

26. Ganesan A, Natesan S, Perumal PG, et al. Anxiolytic, antidepressant and anti-inflammatory activities of methanol extract of Momordica charantiaLinn Leaves (Cucurbitaceae). Iranian J Pharmacol Ther. 2008;7(1):43-47.

27. Saldanha T, Kaspate D, Karmarkar B, et al. Evaluation of Antidepressan Activity of Ethanolic Extract Momordica charantia Unripen Fruit. Int J Pharm Sci \& Drug Res. 2015;7(1):68-71.

28. Vogel HG. Drug Discovery and Evaluation: Pharmacological Assays. 2nd ed. Germany: Springer-Verlag; 2002. p. 559-561.

29. Rao KNV, Swarna K, Banji D, et al. Establishment of two varieties in Tecoma stans of Indian origin pharmacolognostically and pharmacologically. J Phytology. 2010;2(8):92-102.

30. Khare CP. Indian medicinal plants and illustrated dictionary. India: Springer; 2007.

31. Kameshwaran S, Sundaraganapathy R, Thenmozhi S, et al. Assessment of antidepressant activity of methanol and aqueous extract of Tecoma stans flowers using tail suspension test and forced swim test. International $J$ of Pharmacol Res. 2014;4(2):78-82.

32. Mukherjee PK, Kumar V, Kumar NS, et al. The ayurvedic medicine Clitoria ternatea-From traditional use to scientific assessment. $J$ Ethnopharmacol. 2008;120(3):291-301. 
33. Taur DJ, Patil RY. Evaluation of antiasthmatic activity of Clitoria ternatea L. roots. J Ethnopharmacol. 2011;136(2):374-376.

34. Jain NN, Ohal CC, Shroff SK, et al. Clitoria ternatea and the CNS. Pharmacol Biochem and Behav. 2003;75(3):529-536.

35. Sharma AK, Majumdar M. Some observations on the effect of Clitoria ternatea Linn. on changes in serum sugar level and small intestinal mucosal carbohydrase activities in alloxan diabetes. Calcutta Medical Journal. 1990;87:168-171.

36. Devi BP, Boominathan R, Mandal SC. Anti-inflammatory, analgesic and antipyretic properties of Clitoria ternatea root. Fitoterapia. 2003;74(4):345-349.

37. Taranalli AD, Cheeramkuzhy TC. Influence of Clitoria ternatea extracts on memory and central cholinergic activity in rats. Pharmac Biol. 2000;38(1):51-56.

38. Rai KS, Murthy KD, Karanth KS, et al. Clitoria ternatea root extract enhances acetylcholine content in rat hippocampus. Fitoterapia. 2002;73(7):685-689.

39. Parvathi M, Ravishankar K. Evaluation of antidepressant, motor coordination and locomotor activities of ethanolic root extract of Clitoria ternatea. J of Nat Rem. 2013;13(1):19-24.

40. Umadevi P, Murugan S, Jennifer Suganthi S, et al. Evaluation of antidepressant like activity of Cucurbita pepo seed extracts in rats. Int $J$ of Curr Pharma Res. 2011;3(1):108-113.

41. Shoba FG, Thomas M. Study of antidiarrhoeal activity of four medicinal plants in castor-oil induced diarrhoea. J Ethnopharmacol. 2001;76(1):73-76.

42. Kamalakkannan N, Prince PSM. Hypoglycaemic effect of water extracts of Aegle marmelos fruits in streptozotocin diabetic rats. $J$ Ethnopharmacol. 2003;87(2):207-210.

43. Costa-Lotufo LV, Khan MTH, Ather A, et al. Studies of the anticancer potential of plants used in Bangladeshi folk medicine. J Ethonopharmacol. 2005;99(1):21-30.

44. Jagetia GC, Venkatesh P, Baliga MS. Evaluation of radio protective effect of bael leaf (Aegle marmelos) extract in mice. Int J Radiat Biol. 2004;80(4):281-290.

45. Rana BK, Jain AK. Evaluation of anti-fungal activity of essential oil isolated from leaves of the A. marmelos. J Ethnopharmacol. 1997;57(1):29-37.

46. Mazumder R, Bhattacharya A, Mazumder A, et al. Antibacterial evaluation of Aegle marmelos (Correa) Linn. root extract. Phytother Res. 2006;20(1):82-84.

47. Sahare KN, Anandhraman V, Meshram VG, et al. Anti-microfilarial activity of methanol extract of Vitex negundoand Aegle marmelosand their phytochemical analysis. Indian J Exp Biol. 2008;46(2):128-131.

48. Arul V, Miyazaki S, Dhananjayan R. Studies on the anti-inflammatory, antipyretic and analgesic properties of the leaves of Aegle marmelosCorr. J Ethnopharmacol. 2005;96(1-2):159-163.

49. Kothari S, Minda M, Tonpay SD. Anxiolytic and antidepressant activities of methanol extract of Aegle marmelos leaves in mice. Ind. $J$ of Phy Phar. 2010;54(4):318-328.

50. Gonzalez-Trujano ME, Pena EI, Martinez AL, et al. Evaluation of the antinociceptive effect of Rosmarinus officinalis $L$. using three different experimental models in rodents. J Ethnopharmacol. 2007;111(3):476482.

51. Erkan N, Ayranci G, Ayranci E. Antioxidant activities of rosemary (Rosmarinus Officinalis L.) extract, blackseed (Nigella sativa L.) essential oil, carnosic acid, rosmarinic acid and sesamol. Food Chem. 2008;110(1):76-82.
52. Duke JA. Alzheimaretto. J Med Food. 1998;1(1):53.

53. Perry EK, Pickering AT, Wang WW, et al. Medicinal plants and Alzheimer's disease: Integrating ethnobotanical and contemporary scientific evidence. J Altern and Complement Med. 1998;4(4):419-428.

54. Ozarowski M, Mikolajczak PL, Bogacz A, et al. Rosmarinus officinalis $L$. leaf extract improves memory impairment and affects acetylcholinesterase and butyrylcholinesterase activities in rat brain. Fitoterapia. 2013;91:261-271.

55. Abdelhalim A, Karim N, Chebib M, et al. Antidepressant, anxiolytic and antinociceptive activities of constituents from Rosmarinus officinalis. $J$ of Phar \& Pharm Sci. 2015;18(4):448-459.

56. Zargari A. Medicinal plants. Tehran: Tehran University Publications; 1991. p. 77-83.

57. Blumenthal M, Goldberg A, Brinckmann J. Herbal Medicine-Expanded Commission E Mongraphs. In: Newton MA, editor. Integrative Medicine Communications; 2000. p. 230-232.

58. Kuhn MA, Winston D. Herbal therapy and supplements: a scientific and traditional approach. USA: Lippincott Williams \& Wilkins; 2000. p. 210-212.

59. Emamghoreishi M, Talebianpour MS. Antidepressant effect of Melissa officinalis in the forced swimming test. DARU J Pharm Sci. 2009; 17(1):42-47.

60. Jain SC, Sharma RA, Jain R, et al. Antimicrobial screening of Cassia occidentalis Linn in vivo and in vitro. Phytothearpy Res. 1998;12(3):200204.

61. Saganuwan AS, Gulumbe ML. Evaluation of in vitro antimicrobial activities and phytochemical constituents of Cassia occidentalis. Animal Res Intern. 2006;3(3):566-569.

62. Arya V, Yadav S, Kumar S, et al. Antimicrobial activity of Cassia occidentalis L. (leaf) against various human pathogenic microbes. Life Sci Med Res. 2010;2010:1-11.

63. Tona L, Ngimbi NP, Tsakala M, et al. Antimalarial activity of 20 crude extracts from nine African Medicinal plants used in Kinshasa Congo. $J$ Ethnopharmacol. 1999;68(1):193-203.

64. Sharma N, Trikha P, Athar M, et al. In vitro inhibition of carcinogeninduced mutagenicity by Cassiaoccidentalis and Emblica officinalis. Drug and chemical Toxicol. 2000;23(3):477-484.

65. Jafri MA, Subhani MJ, Javed K, et al. Hepatoprotective activity of leaves of Cassia occidentalis Linn against paracetmaol and ethyl alcohol intoxification in rats. $J$ Ethanopharmacol. 1999;66(3):355-361.

66. Verma L, Khatri A, Kaushik B, et al. Antidiabetic activity of Cassia occidentalis Linn. in normal and alloxan-induced diabetic rats. Ind $J$ Pharmacol. 2010;42(4):224-228.

67. Shafeen S, Reddy TS, Arafath S, et al. Evaluation of antianxiety and antidepressant activity of Cassia occidentalis leaves. Asian J Pharm Clin Res. 2012;5(3):1-4.

68. Grubben GJH, Denton OA. Plant Resources of Tropical African vegetables. Netherlands: PROTA Foundation, Backhuys Publishers; 2004.

69. Rathee S, Ahuja D, Rathee P, et al. Cytotoxic and antibacterial activity of Basella alba whole plant: A relatively unexplored plant. Pharmacologyonline. 2010;3:651-658.

70. Roy SK, Gangopadhyay G, Mukherjee KK. Is stem twining form of Basella Alba L. a naturally occurring variant? Current Science. 2010;98(10):1370-1375.

71. Sen K, Goel A, Rawal S, et al. Antimicrobial activity of Basella rubra leaves. Intern J Pharma Sci Res. 2010;1(2):88-91. 
72. Bamidele O, Akinnuga AM, Olorunfemi JO, et al. Effects of aqueous extract of Basella alba leaves on haematological and biochemica parameters in Albino rats. African J Biotechnol. 2015;9(41):6952-6955.

73. Nirmala A, Saroja S, Devi GG. Antidiabetic activity of Basella rubra and its relationship: with the antioxidant property. British Biotechnol J. 2011;1(1):1-9.

74. Saroj V, Rao PS, Rao SK, et al. Pharmacognostical study of Basella alba stem. Intern. J Res Pharma and Biol Sci. 2012;3:1093-1094.

75. Abhinayani, Goud GN, Nagamani KC, et al. Antidepressant and Skeletal Muscle Relaxant Activity of Methanolic Extracts of Basella alba. L. Asian J Biomed Pharma Sci. 2016;6(55):7-10.

76. Pongpan N, Luanratana O, Suntornsuk L. Rapid reversed-phase high performance liquid chromatography for vitexin analysis and fingerprint of Passiflora foetida. Current science. 2007;93(3):378-382.

77. Dhawan K, Kumar S, Sharma A. Anti-anxiety studies on extracts of Passiflora incarnate Linneaus. J Ethnopharmacol. 2001;78(2):165-170.

78. Soulimani R, Younos C, Jarmouni S, et al. Behavioral effects of Passiflor aincarnata $\mathrm{L}$. and its indole alkaloid and flavonoid derivatives and maltol in the mouse. J Ethnopharmacol. 1997;57(1):11-20.

79. Santosh P, Venugopl R, Nilakash AS, et al. Antidepressant activity of methanolic extract of Passiflora foetida leaves in mice. Int $J$ of Pharm Pharm Sci. 2011;3(1):112-115.

80. Chahardehi AM, Ibrahim D, Abolhassani F, et al. Antidepressantlike effect of extracts from Urtica dioica in mice model of depression. In Proceedings of the Annual International Conference, Syiah Kuala University-Life Sciences \& Engineering Chapter; 2012:2(1).

81. Chakravarti RN, Chakravarti D. Andrographolide, the active constituent of Andrographis paniculata Nees; A Preliminary Communication. Ind Med Gaz. 1951;86(3):96-97.

82. Patil R, Chauhan VS, Venkat RP. Anxiolytic and anti-depressant like effects of leaves of Andrographys paniculata. Int $J$ Pharm Bio Sci. 2014;5(3):501-507.

83. De Vry J, Maurel S, Schreiber R, et al. Comparison of Hypericum extracts with imipramine and fluoxetine in animal models of depression and alcoholism. Eur Neuropshycopharmacol. 1999;9(6):461-468.

84. Bach-Rojecky L, Kalodjera Z, Samarzija I. The antidepressant activity of Hypericum perforatum L. measured by two experimental methods on mice. Acta Pharm. 2004;54(2):157-162.

85. Ryan D, Kendall M, Robards K. Bioactivity of oats as it relates to cardiovascular disease. Nutr Res Rev. 2007;20(2):147-162.

86. Guideline on Acute Oral Toxicity (AOT). Environmental Health Safety Monograph Series on Testing and Adjustment No.425. India: Bhaskara Institute of Pharmacy; 2001.

87. Chandrakant J, Mathad P, Mety S, et al. Phytochemical and antidepressant activities of Selaginella bryopteris(L.) Baker on albino mice. Int J App Biol Pharm Tech. 2015;6(4):14-19.

88. Tariq KA, Chishti MZ, Ahmad F, et al. Anthelmintic activity of extracts of Artemisia absinthiumagainst ovine nematodes. Vet Parasitol. 2009;160(1-2):83-88.

89. Kordali S, Cakir A, Mavi A, et al. Screening of chemical composition and antifungal and antioxidant activities of the essential oils from three Turkish Artemisiaspecies. J Agri Food Chem . 2005;53(5):1408-1416.
90. Lopes-Lutz D, Alviano DS, Alviano CS, et al. Screening of chemical composition, antimicrobial and antioxidant activities of Artemisiaessential oils. Phytochemistry. 2008;69(8):1732- 1738.

91. Canadanovic-Brunet JM, Djilas SM, Cetkovic GS, et al. Free-radical scavenging activity of wormwood (Artemisia absinthiumL) extracts. $J$ Sci Food Agric. 2005;85(2):265-272.

92. Nin S, Arfaioli P, Bosetto M. Quantitative determination of some essential oil components of selected Artemisia absinthium plants. $J$ Essential Oil Res. 1995;7(3):271-277.

93. Mahmoudi M, Ebrahimzadeh MA, Ansaroudi F, et al. Antidepressant and antioxidant activities of Artemisia absinthium L. at flowering stage. Afri J Biotechnol. 2009;8(24):7170-7175.

94. Manalachioaie R, Sevastre B, Iulia P, et al. Comparative Evaluation of Antidepressant Effects of Two Hypericum Species (H. perforatum L. and H. maculatum C) in Swiss Mice. Veterinary Medicine. 2010;67(1):115119

95. Tsala DE, Theophile D, Judith N, et al. Screening of Alafia multiflorafor antibacterial, antiradical activity and LD50 investigation. Int $J$ Pharmacol. 2007;3(4):327-333.

96. Foyet HS, Tsala DE, Bouba AA, et al. Anxiolytic and antidepressant-like effects of the aqueous extract of Alafia multiflora stem barks in rodents. Advances in Pharmacological Sciences. 2012:1-8.

97. Khare CP. Indian medicinal plants, an illustrated dictionary. 1st ed India: Springer Private Limited; 2007.

98. Dolati K, Rakhshandeh H, Shafei MN. Evaluation of antidepressant effect of ethanolic extract of Rosa damascena using forced swimming test. Avicenna J Phytomed. 2012;2(1):46-51.

99. Potdar VH, Kibile SJ. Evaluation of antidepressant-like effect of Citrus Maxima leaves in animal models of depression. Iran J Basic Med Sci. 2011;14(5):478-483.

100. Singh HK, Dhawan BN. The effect of Bacopa monniera Linn (Brahmi) extract on avoidance responses in rat. $J$ Ethanopharmacol. 1982;5(2):205-214.

101. Sen S, Chakraborty R, Sridhar C, et al. Free radicals, antioxidants, Diseases and phytomedicines: Current status and Future prospect. Int $J$ Pharma Sci Rev and Res. 2010;3(1):91-100.

102. Valko M, Leibfritz D, Monco J, et al. Free radicals and antioxidants in normal physiological functions and human disease. Int J Biochem Cell Biolo. 2007;39(1):44-84

103. Mohan H. Cell Injury and cellular Adaptations. In: Textbook of Pathology. India: Jaypee Brothers medical publishers; 2010. p. 21-34.

104. Kumar V, Abbas AK, Fausto N. Cellular Adaptations, cell injury and cell death. In: Robbins, Cotran, editors. Pathologic basis of disease. Pennsylvania: Saunders; 2009.

105. Sudharani D, Krishna KL, Deval K, et al. Pharmacological profile of Bacopa monnieri: a review. Int J Pharma. 2011;1(1):15-23.

106. Mannan A, Abir AB, Rahman R. Antidepressant-like effects of methanolic extract of Bacopa monniera in mice. BMC Complement Altern Med. 2015;15(1):337. 